\title{
Dinamika Kebijakan Resolusi Konflik Tenurial Kawasan Hutan Era Joko Widodo
}

\author{
Totok Dwi Diantoro \\ Program Sutdi Ilmu Hukum, Fakutas Hukum Universitas Gadjah Mada, Indonesia \\ *Korespondensi: totok.dwi@mail.ugm.ac.id
}

\section{Info Artikel}

Diajukan: 14-08-2020

Direview: 18-08-2020

Direvisi: $24-08-2020$

Diterima: 25-08-2020

DOI: $10.18196 / \mathrm{mls} . v 1 i 4.20272$

\begin{abstract}
Abstrak
Konflik tenurial masih banyak terjadi di berbagai wilayah di Indonesia. Tercatat 9.124 konflik pertanahan terjadi pada tahun 2015-2019 dalam beberapa sektor, yaitu perkebunan, transmigrasi, dan kawasan hutan. Pemerintah berupaya menekan laju pertumbuhan konflik tenurial melalui produk hukum Peraturan Presiden dan Peraturan Menteri. Namun, dalam kurun waktu lima tahun masa pemerintahan Joko Widodo periode pertama, persoalan konflik tenurial tak
\end{abstract} kunjung terselesaikan. Penelitian ini bertujuan untuk mengetahui bagaimana dinamika kebijakan resolusi konflik tenurial khususnya pada kawasan hutan di era Joko Widodo. Penelitian ini menilai upaya intervensi kebijakan bagi penyelesaian akar permasalahan atau sumber konflik tenurial. Hasil penelitian menunjukkan bahwa pembentukan peraturanperaturan terkait resolusi konflik tenurial di era Joko Widodo tidak menunjukkan perkembangan signifikan ke arah yang lebih baik. Padahal, awalnya berbagai peraturan yang telah ada memberikan harapan cukup positif terhadap penyelesaian konflik tenurial pada kawasan hutan. Namun, selepas itu kebijakan-kebijakan lanjutan yang dilakukan pemerintah justru menunjukkan hasil yang stagnan. Peraturan-peraturan yang dibutuhkan sebagai dasar penyelesaikan konflik tenurial tidak cukup memadai. Tumpang tindih pengaturan juga terjadi, karena persoalan konflik tenurial bersifat lintas sektor.

Kata kunci : resolusi konflik; kebijakan; tenurial

\section{Pendahuluan}

Konflik agraria selalu mengalami peningkatan dari tahun ke tahun. Sepanjang era Presiden Susilo Bambang Yudhyono (2010-2014), terdapat 1.308 konflik agraria yang terjadi. ${ }^{1}$ Sementara memasuki era Presiden Joko Widodo pada 2015-2019, berdasarkan catatan Konsorsium Pembaharuan Agraria (KPA) konflik agaria tercatat sebanyak 2.047 kasus. ${ }^{2}$ Data tersebut menunjukkan bahwa konflik tenurial meningkat lebih dari 50 persen sepanjang 5 tahun terakhir. KPA juga merilis catatan sepanjang tahun 2019 terjadi 279 konflik agraria seluas 734.239,3 ha. Jumlah masyarakat yang terdampak konflik tersebut sebanyak 109.042 kepala keluarga yang tersebar di 420 desa di seluruh

\footnotetext{
1 CNN Indonesia, "Konflik Lahan Era Joko Widodo 2 Kali Lipat dari 2 Periode SBY", https://www.cnnindonesia.com/nasional/20200106132321-20-462771/konflik-lahan-era-Joko Widodo-2kali-lipat-dari-2-periode-sby, diakses 29 September 2020

${ }^{2}$ Ibid.
} 
provinsi di Indonesia. ${ }^{3}$ Sementara Kementerian Lingkungan Hidup dan Kehutanan (KLHK) menyebut sepanjang tahun 2015-2019 terdapat 9.124 konflik pertanahan dalam beberapa sektor, yaitu perkebunan, transmigrasi, dan kawasan hutan. ${ }^{4}$

Dalam konteks kawasan hutan, Fakultas Kehutanan UGM menyatakan bahwa terdapat 2,8 juta ha perkebunan kelapa sawit di dalam kawasan hutan, dimana $35 \%$ diantaranya dikelola oleh masyarakat, dan selebihnya (65\%) dikuasai oleh korporasi. ${ }^{5}$ Konflik pada kawasan hutan yang lain juga dapat ditemukan kaitannya dengan pertambangan. Pada tahun 2011, Komisi Pemberantasan Korupsi (KPK) pernah menyampaikan ada 1.052 izin yang mencapai hingga 15 juta ha yang tumpang-tindih dengan kawasan hutan. ${ }^{6}$ Sementara, Fakultas Kehutanan Institut Pertanian Bogor (IPB) lebih fantastis lagi, menyatakan bahwa hingga tahun 2017 setidaknya terdapat 17,4 juta ha penguasaan tanah di dalam kawasan hutan, termasuk izin tambang dan perkebunan. ${ }^{7}$

Kebijakan resolusi konflik tenurial sumber daya alam sendiri yang telah lama diintroduksi (utamanya pasca reformasi) muncul dari tuntutan-tuntutan mendesak yang tidak bisa dihindari. Terbitnya TAP MPR No. IX/MPR-RI/2001 tentang Pembaruan Agraria dan Pengelolaan Sumber Daya Alam menunjukkan dua hal penting. Pertama, menjadi bukti adanya ketimpangan struktur penguasaan tenurial yang berakar dari regulasi yang tidak harmoni dan pada akhirnya menimbulkan konflik di lapangan. Kedua, juga sebagai bukti mengenai urgensi resolusi konflik. Konsideran TAP MPR tersebut mengungkapkan bahwa pengelolaan sumber daya alam selama ini telah menurunkan kualitas lingkungan, menimbulkan ketimpangan-ketimpangan struktur penguasaan, pemilikan, penggunaan dan pemanfaatannya, serta menimbulkan berbagai konflik. Ditegaskan juga mengenai peraturan perundang-undangan yang berkaitan dengan pengelolaan sumber daya agraria/sumber daya alam saling tumpang-tindih dan bertentangan.

Pada kasus tenurial kawasan hutan, kebijakan resolusi konflik yang sifatnya operasional pada era pemerintahan Joko Widodo pertama kali dipaparkan dalam program Nawacita. Salah satu poin penting adalah adanya misi penyelesaian konflik agraria berkaitan dengan eksistensi kawasan hutan. Melalui Peraturan Presiden No. 2

\footnotetext{
${ }^{3}$ Komisi Nasional Hak Asasi Manusia, "Komnas HAM Ingatkan Potensi Eskalasi Konflik Agraria", sumber: https://www.komnasham.go.id/index.php/news/2020/1/7/1302/komnas-ham-ingatkan-potensieskalasi-konflik-agraria.html diakses 2 April 2020

${ }^{4}$ Komisi Nasional Hak Asasi Manusia, "Komnas HAM Dorong Penyelesaian Konflik Agraria HAM", https://www.komnasham.go.id/index.php/news/2019/12/12/1279/komnas-ham-dorong-penyelesaian-

konflik-agraria-ham.html, diakses 2 April 2020

5 Tommy Apriando, "Kajian UGM: 2,8 Juta Hektar Kebun Sawit di Kawasan Hutan, 65\% Milik Pengusaha, Solusinya?", https://www.mongabay.co.id/2018/11/04/kajian-ugm-28-juta-hektar-kebunsawit-di-kawasan-hutan-65-milik-pengusaha-solusinya/, diakses 2 April 2020

${ }^{6}$ Anonim, 2013, Menuju Kawasan Hutan yang Berkepastian Hukum dan Berkeadilan, Prosiding Semiloka (integrated white paper), Komisi Pemberantasan Korupsi (KPK), Jakarta 13 Desember 2012, hlm. 4

${ }^{7}$ Hariadi Kartodihardjo, "Titik Kritis Penyelesaian Penguasaan Tanah Dalam Kawasan Hutan, Opini Warta Online Agroindonesia", http://agroindonesia.co.id/2017/12/titik-kritis-penyelesaian-penguasaantanah-dalam-kawasan-hutan-2/, diakses 2 April 2020
} 
Tahun 2015 tentang Rencana Pembangunan Menengah Nasional (RPJMN) 2015-2019, pemerintah menjanjikan program reforma agraria dan perhutanan sosial sebagai dasar kebijakan resolusi konflik tenurial yang telah lama berjalan. Program reforma agraria tersebut menawarkan komitmen pengalokasian Tanah Objek Reforma Agraria (TORA) dari kawasan hutan sedikitnya seluas 4,1 juta ha. ${ }^{8}$ Sementara untuk perhutanan sosial, dijanjikan lahan seluas 12,7 juta ha di dalam kawasan hutan yang akan dibuka aksesnya bagi masyarakat melalui berbagai skema pemberian izin maupun konsesi. ${ }^{9}$

Kajian kebijakan resolusi konflik tenurial kawasan hutan ini mempunyai arti penting utamanya terkait dengan seberapa jauh berbagai produk kebijakan yang telah diterbitkan oleh pemerintahan Joko Widodo ini memberikan dampak dalam narasi penyelesaian akar persoalan. Adanya ketimpangan akses dan kontrol terhadap sumber daya alam sebagaimana terjadi di tengah masyarakat merupakan hal yang penting untuk segera diselesaikan. Selain itu, pada saat yang sama kajian kebijakan tersebut juga dapat menjadi semacam lesson learn bagi kepentingan improvisasi menuju kepada suatu bentuk fomulasi kebijakan resolusi yang lebih tepat sasaran.

Sementara dari sisi topik studi resolusi konflik, penelitian ini dapat memberikan kontribusi untuk memperkaya diskursus mengenai resolusi konflik. Diskursus tersebut baik menyangkut dengan mekanisme maupun dalam keberadaannya sebagai kebijakan spesifik menjadi terobosan penyelesaian konflik.

\section{Metode Penelitian}

Penelitian Hukum Normatif dapat didefinisikan sebagai penelitian yang meletakkan kaidah atau aturan hukum sebagai objek penelitian, ${ }^{10}$ dan melakukan kajian terhadap bahan pustaka atau data sekunder yang telah dikumpulkan. ${ }^{11}$ Dengan mengambil jenis penelitian hukum normatif yang bersifat deskriptif-kualitatif, penelitian dalam rangka penyusunan tulisan ini mendasarkan pada kajian kebijakan/peraturan perundang-undangan sebagai metode utamanya. Kajian kebijakan yang dimaksud di dalam studi ini adalah penelitian terhadap berbagai produk hukum yang selain keberadaannya diformulasikan sebagai instrumen resolusi konflik, juga dalam posisinya yang memiliki pengaruh relevan dalam rangka resolusi konflik tenurial kawasan hutan. Di samping analisis regulasi, peneliti juga melakukan kajian pustaka dari sumber data sekunder yang lain (laporan lapangan terkait implementasi peraturan) dalam rangka untuk menyempurnakan dan melengkapi sudut pandang studi.

\footnotetext{
${ }^{8}$ Anonim, 2015. Peraturan Presiden Nomor 2 Tahun 2015 tentang RPJMN 2015-2019, Buku I hlm. 8081

${ }^{9}$ Ibid

${ }^{10}$ Mukti Fajar dan Yulianto Achmad, 2010, Dualisme Penelitian Hukum Normatif dan Empiris, Pustaka Pelajar, Yogyakarta, hlm. 34.

${ }^{11}$ Soerjono Soekanto dan Sri Mamudji, 2006, Penelitian Hukum Normatif, Raja Grafindo Persada, Jakarta, hlm. 12
} 
Penelitian ini sendiri membatasi pada kajian kebijakan resolusi konflik tenurial pada kawasan hutan di era Joko Widodo terutama pada periode pemerintahannya yang pertama. Dengan alasan: pertama, periode pemerintahan yang pertama (2014-2019) secara khusus melansir program reforma agraria dan perhutanan sosial sebagai bagian dari kebijakan penyelesaian konflik sebagaimana dituangkan di dalam Perpres No. 2 Tahun 2015 tentang RPJMN 2015-2019. Dan kedua, dengan telah berakhirnya periode pertama maka diasumsikan sudah ada berbagai laporan evaluasi efektifitas implementasi dari kebijakan resolusi konflik tenurial yang bersangkutan.

\section{Hasil dan Pembahasan}

\subsection{Konsep Resolusi Konflik Tenurial}

Menurut pandangan Kriesberg sebagaimana dikutip oleh Riza Noer Arfani, konflik memiliki semacam 'riwayat' dalam kehidupannya berupa tahapan-tahapan yang sifatnya siklikal, bermula dari sumber, kemunculannya, pemicunya, ekskalasi dan deekskalasinya, terminasi, sampai ke hasil dan konsekuensinya, kemudian berawal lagi sebagai sumber konflik yang baru, dan seterusnya. ${ }^{12}$ Secara lebih sederhana mengenai sumber konflik itu sendiri, Arfani yang juga merujuk pada Kriesberg menyebut pada dasarnya konflik merupakan suatu kondisi sosial ketika dua pihak atau lebih memanifestasikan keyakinan mereka akan suatu tujuan yang saling berbeda. ${ }^{13}$ Riza Noer Arfani menekankan bahwa kondisi tersebut tidak saja aktual, tetapi juga laten. Menurutnya, hal itu berasal dari bangunan teoritik atau asumsi dasar manusia dan proses sosial yang menyertainya dimana secara internal manusia memiliki insting agresif, mudah frustasi, dan lain sebagainya, yang dalam interaksinya dapat mengarah pada proses-proses sosial yang disintegrated. Hal-hal inilah, baik yang secara laten maupun manifes menjadi sumber konflik.

Timbulnya konflik dipastikan membawa dampak negatif yang merugikan bagi para pihak yang terlibat. Oleh karena itu, diperlukan suatu upaya intervensi guna menyelesaikan permasalahan yang terjadi sampai pada sumber atau akar permasalahannya. Intervensi dalam hal ini dilakukan terhadap suatu obyek tertentu yang memiliki kepentingan yang saling berlawanan. Intervensi penyelesaian tersebut kemudian seringkali dikenal sebagai resolusi konflik. Menurut Weitman \& Weitzman sebagaimana dikutip oleh Suhardono mendefinisikan resolusi konflik sebagai sebuah upaya untuk menyelesaikan permasalahan secara bersama. ${ }^{14}$ Definisi tersebut menunjukkan bahwa resolusi konflik yang ideal tidak dapat dicapai apabila hanya dijalankan oleh salah satu pihak secara tunggal. Sebaliknya, resolusi konflik harus mengakomodasi berbagai kepentingan dari setiap pihak yang terlibat. Secara singkat,

\footnotetext{
${ }^{12}$ Lihat Riza Noer Arfani , "Governance Sebagai Pengelolaan Konflik”, Jurnal Ilmu Sosial dan Ilmu Politik, Vol. 8 No. 3, Maret 2005, hlm. 317

${ }^{13} \mathrm{Ibid}$

${ }^{14}$ Wisnu Suhardono, "Konflik dan Resolusi”, Jurnal Sosial dan Budaya Syar'I Vol. II No. 1 Juni 2015, hlm. 4.
} 
resolusi konflik diartikan sebagai mekanisme melalui dua pendekatan yaitu adversial dengan intervensi kelembagaan pengadilan dan win-win solution baik dengan fasilitasi atau tanpa fasilitasi pihak ketiga.

Kedua pendekatan tersebut, masing-masing memiliki karakteristik yang berbeda dalam hal pemenuhan kepentingan bagi para pihak. Proses penyelesaian melalui lembaga pengadilan menghasilkan kesepakatan yang bersifat adversarial atau saling berlawanan, sehingga belum mampu merangkul kepentingan bersama, dan cenderung memunculkan masalah baru. ${ }^{15}$ Sementara, proses penyelesaian di luar pengadilan yang bersifat win-win solution, cenderung menghasilkan penyelesaian yang komprehensif dalam kebersamaan dan tetap dapat menjaga hubungan baik. ${ }^{16}$ Hal tersebut dikarenakan keterlambatan proses penyelesaian yang bersifat prosedural dan administratif dapat dihindari. ${ }^{17}$

Dewasa ini, konflik penguasaan sumber daya alam yang terjadi baik antara masyarakat dengan pemerintah, masyarakat dengan perusahaan, maupun antar pemegang izin menjadi isu makro yang cukup kompleks. Menurut Buckles, terdapat empat penyebab timbulnya konflik sumber daya alam termasuk hutan, yaitu : ${ }^{18}$

(1) adanya perbedaan akses antar aktor sosial dan/atau institusi terhadap pusat kekuasaan;

(2) Aktivitas manusia yang mengubah keseimbangan ekosistem di suatu wilayah dapat menimbulkan masalah lingkungan di wilayah lainnya (negative externalities);

(3) Adanya peningkatan kelangkaan sumber daya alam; dan

(4) Ideologi dan etik yang dianut oleh suatu kelompok masyarakat yang berpegaruh terhadap pengelolaan sumber daya alam dan pengelolaan konflik atasnya.

Disamping itu, konflik penguasaan sumber daya alam seringkali terjadi karena beberapa alasan, diantaranya yaitu ketidakjelasan status hukum atas kepemilikan sumber daya oleh suatu pihak, penataan regulasi yang tidak harmonis, dan adanya ketimpangan penguasaan sumber daya akibat praktik penyelenggaran pengelolaan yang tidak maksimal. Pertentangan kepentingan atas penguasaan sumber daya, terutama berkaitan dengan status hukum atas suatu objeknya kemudian sering disebut sebagai konflik tenurial.

\footnotetext{
15 Badan Pertanahan Nasional, 2007, Reforma Agraria: Mandat Politik, Konstitusi, dan Hukum Dalam Rangka Mewujudkan “Tanah untuk Keadilan dan Kesejahteraan Rakyat”, Badan Pertanahan Nasional, Jakarta, hlm. 23.

${ }^{16}$ Ibid

${ }^{17}$ Ibid

${ }^{18}$ Gamal Pasya, 2017, Penanganan Konflik Lingkungan: Kasus Pengelolaan Kawasan Hutan Lindung Bukit Rigis Lampung, Gramedia Pustaka Utama, Jakarta, hlm. 3
} 
Secara harafiah, tenurial berasal dari kata "tenure" yang berasal dari bahasa latin "tenere" yang berarti memelihara, memegang, dan memiliki ${ }^{19}$ Persepsi tenurial dapat dikelompokkan dalam dua perspektif. Pertama, konsep hak milik pribadi dimulai dengan ide John Locke. Kedua, konsepsi kepemilikan bersama (komunal) yang dikemukakan oleh Jean Bodin dan George Jelinek. ${ }^{20}$ Di Indonesia, kebijakan kehutanan umumnya didasarkan pada model kepemilikan dan penguasaan negara atas lahan hutan dan sumber dayanya. ${ }^{21}$ Sejak tahun 1970-an, pemerintah telah menetapkan sekitar dua pertiga dari tanah negara sebagai kawasan hutan negara, yang dikontrol dengan kuat dan disahkan di bawah yurisdiksi Kementerian Lingkungan Hidup dan Kehutanan. ${ }^{22}$

Menurut Anne M. Larson, tenurial merujuk pada kandungan atau hakikat dari hak dan jaminan atas hak. Hak disini diartikan dari sudut pandang yang berbeda, yaitu terhadap hak yang tumpang tindih atau terdapat dua orang atau lebih secara bersamaan mengaku berhak atas sumber daya yang sama. ${ }^{23}$ Lebih lanjut ia menjelaskan bahwa hakikat hak tenurial dapat dijabarkan baik secara de jure maupun de facto. Hak menurut undang-undang atau de jure berkenaan dengan seperangkat aturan yang dibuat dan dilindungi oleh negara (misalnya, bukti kepemilikan yang terdaftar, kontrak konsesi,peraturan perundang-undangan tentang kehutanan). Sedangkan, hak de facto merupakan pola interaksi yang ditetapkan di luar lingkup hukum formal. Ini mencakup hak ulayat, seperangkat aturan dan peraturan masyarakat yang diwarisi dari nenek moyang dan diterima, ditafsirkan ulang, dan ditegakkan oleh masyarakat, dan yang mungkin diakui atau tidak oleh negara. ${ }^{24}$ Berdasarkan uraian yang dikemukaan oleh Anne M. Larson tersebut, dapat diambil satu kesimpulan bahwa untuk memperoleh kepastian penguasaan atas suatu sumber daya secara kuat dan legitimate, maka syarat baik secara de jure maupun de facto haruslah terpenuhi. Selain itu, dari segi HAM Negara wajib melindungi warga negara atas sumber daya agraria dari ancaman pihak non-negara. Kewajiban itu baik dalam bentuk mencegah ataupun menindak pihak yang melanggar. ${ }^{25}$ Negara juga memiliki kewajiban pemenuhan dimana Negara wajib memenuhi hak warga negara terkait dengan usaha-usahapertanian Negara. Kegagalan

\footnotetext{
${ }^{19}$ Agus Marzuki, Disertasi, : "Penyelesaian Konflik Tenurial Kawasan Hutan Register 45 Mesuji Lampung dalam Perspektif Keadilan” (Yogyakarta : UGM, 2016), hlm. 101

20 Khairul Anwar, "The Pattern of Interaction Politicalactors on Situations of Tenurialconflict in Watershedcase of Palm Oil in Kampung Dosan", Journal of Science and TechnologyPolicy Management Vol. 10 No. 5, 2019, hlm. 1100

${ }^{21}$ Ahmad Maryudi dkk. "The emerging power of peasant farmers in the tenurial conflicts over the uses of state forestland in Central Java, Indonesia”, Journal Forest Policy and Economics Volume 67, June 2016, hlm. 70

22 Ibid

${ }^{23}$ Anne M. Larson, 2013, Hak Tenurial dan Akses ke Hutan, Center for Intenational Forestry Research, Bogor, hlm. 9.

${ }^{24}$ Ibid, hlm. 29.

25 Erlina, "Kebijakan Reformasi Agraria pada Masa Pemerintahan Joko Widodo Ditinjau dari Kajian HAM dan Gender", Riau Law Journal Vol. 1 No.2, November 2017, hlm. 257
} 
negara melaksanakan kewajibannya, merupakan bentuk pelanggaran hak asasi manusia. $^{26}$

Kepastian penguasaan atas suatu sumber daya berkaca pada pengaturan hak ulayat dalam Undang-Undang No. 5 Tahun 1960 tentang Peraturan Dasar Pokok-Pokok Agraria menyatakan bahwa eksistensi hak ulayat diakui. Pasal 5 Undang-Undang a quо yang menyatakan bahwa "hukum agraria yang berlaku atas bumi, air dan ruang angkasa adalah Hukum Adat, sepanjang tidak bertentangan dengan kepentingan nasional dan negara yang berdasarkan atas persatuan bangsa dengan sosialisme Indonesia serta dengan peraturan yang tercantum dalam undang-undang ini dan dengan peraturanperaturan lainnya, segala sesuatu dengan mengindahkan unsur-unsur yang berdasarkan pada hukum agama". Namun demikian, terdapat batasan yang secara expressive verbis diatur dalam Pasal 3 yang secara tidak langsung mereduksi muatan dalam Pasal 5 UU $a$ quo. Pasal 3 menyatakan bahwa pelaksanaan hak ulayat harus "sesuai dengan kepentingan nasional dan negara yang berdasarkan atas persatuan bangsa serta tidak boleh bertentangan dengan undang-undang dan peraturan-peraturan lain yang lebih tinggi".

Sementara berkaitan dengan klasifikasi hak yang terkandung dalam tenurial, menurut Food and Agriculture Organization (FAO) sebagaimana dikutip oleh Sylviani \& Ismatul Hakim, ${ }^{27}$ menyatakan bahwa secara teori tenurial digambarkan sebagai bundle of rights yaitu sekumpulan hak atas tanah yang disederhanakan menjadi 3 (tiga) hak, yaitu hak pakai, hak mengontrol dan hak mentransfer. Pertama, hak pakai yaitu hak untuk menggunakan lahan (pengembalaan, menanam subsisten, mengumpulkan produkproduk kehutanan: kayu bakar, madu dan lain-lain). Kedua, hak untuk mengontrol yaitu hak untuk membuat keputusan bagaimana lahan harus digunakan, termasuk memutuskan apa yang harus ditanam dan mengambil keuntungan finansial dari penjualan tanaman, dan ketiga, hak mentransfer yaitu hak untuk menjualatau menggadaikan tanah, hak untuk menyampaikan kepada orang lain melalui intrakomunitas relokasi, untuk mengirimkan tanah kepada ahli waris melalui warisan dan realokasi hak guna dan kontrol.

Tenurial merupakan kunci penting bagi skema pembagian manfaat atas kekayaan sumber daya. Menurut Anne M. Larson, secara sederhana terdapat dua hak yang terkandung dalam sistem tenurial yaitu hak ekslusi dan hak pengalihan. Hak eksklusi diartikan sebagai hak untuk menetapkan siapa saja yang boleh menggunakan sumber daya dan siapa yang dilarang menggunakannya ${ }^{28}$ Hak eksklusi ini merupakan elemen yang cukup penting untuk mengendalikan konflik tenurial yang terjadi di masyarakat. Disisi lain, hak ekslusi juga dapat menjaga kualitas sumber daya, mengingat hak ini

\footnotetext{
${ }^{26}$ Ibid

27 Sylviani \& Ismatul Hakim, "Analisis Tenurial dalam Pengembangan Kesatuan Pengelolaan Hutan (KPH): Studi Kasus KPH Gedong Wani, Provinsi Lampung”, JURNAL Penelitian Sosial dan Ekonomi Kehutanan Vol. 11 No. 4 Desember 2014, hlm. 310

${ }^{28}$ Anne M. Larson, Op. Cit., hlm. 14.
} 
juga disertai dengan tata cara penggunaan suatu sumber daya. Sedangkan, hak pengalihan dipahami sebagai menjual, mengalihkan atau menyewakan lahan yang juga mencakup hak-hak lain. ${ }^{29}$ Seperti misalnya, masyarakat yang memiliki hak atas lahan yang diakui oleh negara, dapat dipastikan bahwa ia memiliki hak pengalihan resmi.

Konflik sumber daya alam dapat digambarkan sebagai bentuk hubungan sosial yang tidak harmonis di antara masyarakat, pemerintah, dan pengusaha atau investor. ${ }^{30}$ Hubungan yang tidak harmonis tersebut diawali ketika pemerintah melakukan monopoli dan manipulasi proses eksploitasi sumber daya alam, sehingga terjadi perbedaan akses. $^{31}$ Konflik atas tanah atau sumber daya alam juga lahir sebagai akibat dari kontradiksi antara pengaturan tenurial yang berusaha diterapkan Pemerintah dengan pengaturan yang eksis sebelumnya. Pemerintah memberlakuan sistem tenurial Barat pada sistem sebelumnya yang mayoritas merupakan sistem adat. ${ }^{32}$ Dalam banyak kasus, pengaturan ini menggantikan sistem tenurial yang beragam dan kompleks yang digunakan oleh masyarakat lokal dengan pengaturan yang disederhanakan dan dikembangkan oleh Belanda sebelumnya. ${ }^{33}$ Perbedaan persepsi tentang hutan juga menjadi faktor penyebab terjadinya konflik antara masyarakat dan kehutanan, dimana masyarakat menganggap hutan pada saat masih terdapat hutan fisik, sebaliknya kehutanan berdasarkan UU 41 tahun 1999 tidak demikian. ${ }^{34}$ Beberapa masyarakat menganggap tanah adalah milik keluarga, leluhur atau kelompok masayakat pendahulu yang telah mendiami lahan sejak lama. Pemahaman tentang pertanahan yang salah, dan adanya anggapan bahwa tanah yang sudah lama dikelola pada suatu saat akan diberikan haknya oleh pemerintah menjadi salah satu sebab konflik tenurial. ${ }^{35}$

Hingga saat ini, dari sekian banyak konflik tenurial yang terjadi dan menahun, persoalannya berkutat pada seputar dengan isu hak dan akses, distribusi sumber daya, dan manajemen serta regulasi. ${ }^{36}$ Konflik tenurial pada kawasan hutan merupakan salah satu konflik yang kerap kali terjadi pada masa kepimpinan era presiden Joko Widodo. Tenurial lahan hutan berkenaan dengan siapa yang memiliki lahan hutan, dan siapa yang memanfaatkan, mengelola dan memutuskan perihal sumber daya hutan. Tenurial lahan hutan menentukan siapa yang diizinkan untuk menggunakan sumber daya apa,

\footnotetext{
${ }^{29} \mathrm{Ibid}$.

${ }^{30}$ San Afri Awang, 2007, Politik Kehutanan Masyarakat, Kreasi Wacana, Yogyakarta, hlm. 19

${ }^{31}$ Ibid.

${ }^{32}$ Ketut Deddy, "Community Mapping, Tenurial Rights and Conflict Resolution in Kalimantan", dalam Fadzilah Madjid Cooke (Ed.), 2006, State, Communitiesand Forests in Contemporary Borneo, ANU Press, Canberra, hlm. 91

${ }^{33}$ Ibid

${ }^{34}$ Joni Saputra dan Endang Dewata, "Tenurial conflict between parties in the Technical Implementation Unit of the Banjar Regency Forest Management Unit in the Province of South Kalimantan", The 1st International Conference on Environmental Sciences (ICES2018), hlm. 7

35 Luchman Hakim dkk. "Peran dan Dampak Konflik Tenurial Kehutanan bagi Pengelolaan Keanekaragaman Hayati di Kawasan Cagar Biosfer di Jawa Timur", Jurnal Hutan Tropis, Volume 6, Nomor 1, Maret 2018, hlm. 48

${ }^{36}$ Jeffrey Y. Campbell, "Differing Perspectives on Community Forestry in Indonesia" dalam Carol J. Pierce Colfer dan Ida Aju Pradnja Resosudarmo (Ed.), 2002, Which Way Forward? People, Forests, and Policymaking in Indonesia, RFF Press Book, Washington, hlm. 112
} 
dengan cara bagaimana, selama berapa lama, dan dengan syarat apa, serta siapa yang berhak mengalihkan hak kepada pihak lain dan bagaimana caranya. ${ }^{37}$ Berdasarkan catatan KPA, semasa era SBY pada 2010-2014 terdapat 1.308 konflik. ${ }^{38}$ Lalu konflik tenurial pada kawasan hutan di era presiden Joko Widodo terbilang cukup tinggi yaitu sebanyak 2.047 kasus. Kawasan hutan menjadi sumber konflik karena banyak pihak yang berkepentingan ikut serta mengelola hutan.

Berdasarkan kajian Forest Watch Indonesia (FWI), pada kurun waktu 2013-2016, terdapat fenomena kehilangan hutan atau deforestasi seluas 1,8 juta hektare di delapan Provinsi. Perubahan tutupan hutan yang tertinggi terjadi di Provinsi Kalimantan Timur dengan luas sekitar 472 ribu hektare, di ikuti oleh Provinsi Sulawesi Tengah dengan luas sekitar 373 ribu hektare dan Kalimantan Barat yaitu sebesar 241 ribu hektare. ${ }^{39}$ Pada periode yang sama, juga terdapat 8,9 juta hektare areal penggunaan lahan yang tumpang tindih antara Hak Pengusahaan Hutan (HPH), Hutan Tanaman Industri (HTI), perkebunan kelapa sawit dan pertambangan. ${ }^{40}$ Bahkan sekitar 526 ribu hektare wilayah adat tumpang tindih dengan konsesi-konsesi tersebut. ${ }^{41}$ Adanya hak yang tumpang tindih dalam pengelolaan hutan dan lahan serta kebijakan yang mengarah pada deforestasi tentu berpotensi memunculkan konflik tenurial baik antara masyarakat dengan pemerintah maupun masyarakat dengan perusahaan.

Padahal konflik kehutanan dapat menciptakan iklim yang tidak kondusif serta memperberat upaya-upaya dalam mewujudkan pengelolaan sumberdaya yang lestari. ${ }^{42}$ Hal tersebut ditinjau dari berbagai sisi, Pertama, dari sisi ekonomi konflik mengakibatkan tidak adanya insentif dan kepastian dalam berusaha di bidang kehutanan. Kedua, dari sisi sosial konflik bisa membawa tuntutan (claiming) atas wilayah sehingga dapat mempersulit upaya pengelolaan hutan yang memperhatikan aspek bentang alam dan satu kesatuan ekosistem. Ketiga, dari sisi ekologis mengancam daya dukung (carrying capacity) kawasan hutan, dan akhirnya hanya menyisakan kerusakan sumberdaya yang makin besar. ${ }^{43}$

Melihat banyaknya konflik tenurial yang terjadi pada kawasan hutan, Presiden Joko Widodo menerbitkan dua instrumen hukum sebagai upaya untuk menekan laju pertumbuhan konflik tenurial pada kawasan hutan yang jumlahnya kian meningkat dari tahun ke tahun. Ada pun instrumen tersebut yaitu Peraturan Presiden Nomor 88 Tahun 2017 tentang Penyelesaian Penguasaan Tanah dalam Kawasan Hutan dan Peraturan Menteri Lingkungan Hidup dan Kehutanan (Permen LHK) Nomor P.17 Tahun 2018

\footnotetext{
${ }^{37}$ Anne M. Larson, Op. Cit., hlm. 8

${ }^{38}$ CNN Indonesia, Op.Cit.

39 Forest Watch Indonesia, "Silang Sengkarut Pengelolaan Hutan dan Lahan di Indonesia", https://fwi.or.id/wp-content/uploads/2017/12/executivesummary8des17_final.pdf, diakses pada 29 September 2020

40 Ibid

${ }^{41}$ Ibid

42 Mustofa Agung Sardjono, 2004, Mosaik Sosiologi Kehutanan : Masyarakat Lokal, Politik dan Kelestarian Sumberdaya, Debut Wahana Sinergi, Yogyakarta, hlm. 149

${ }^{43}$ Ibid
} 
tentang Tata Cara Pelepasan Kawasan Hutan dan Perubahan Batas Kawasan Hutan untuk Sumber Tanah Obyek Reforma Agraria (TORA). Perihal TORA sendiri, dalam Permen LHK Nomor P.17 Tahun 2018 terdapat pengaturan mengenai Tanah Obyek Reforma Agraria (TORA). Berdasarkan Pasal 1 angka 7, TORA didefinisikan sebagai tanah yang dikuasai oleh negara untuk didistribusikan atau diredistribusikan dalam rangka reforma agraria. ${ }^{44}$ Pada tahun 2018, pemerintah telah mengalokasikan anggaran penyelesaian TORA sebesar Rp 826 milliar, untuk memenuhi penyelesaian TORA seluas 1,6 juta hektare. ${ }^{45}$

Sebagai pijakan dari kebijakan-kebijakan resolusi konflik tenurial sumber daya alam yang dikeluarkan oleh Pemerintah, TAP MPR No. IX/MPR-RI/2001 memformulasikan prinsip-prinsip pembaruan agraria dan pengelolaan sumber daya alam yang seharusnya dijadikan pedoman tindak lanjut bagi kebijakan yang lebih operasional. Maria Sumardjono meringkas prinsip tersebut pada tiga prinsip: demokratis, keadilan, dan keberlanjutan. ${ }^{46}$ Demokratis berkaitan dengan dimensi kesetaraan antara pemerintah dengan rakyat, pemberdayaan masyarakat dan upaya perwujudan good governance dalam penguasaan dan pemanfaatan sumber daya agraria/sumber daya alam. Keadilan, yaitu berada dalam dimensi filosofis baik keadilan intergenerasi maupun antargenerasi terkait akses dan kontrol terhadap sumber daya agraria/sumber daya alam. Sedangkan keberlanjutan, yaitu prinsip yang berada pada dimensi kelestarian fungsi dan manfaat sumber daya agraria/sumber daya alam yang berdaya guna dan berhasil guna. Ketiga prinsip tersebut berada pada rentang saling terkait dan tidak dapat dipisahkan satu sama lain.

\subsection{Dinamika Resolusi Konflik Tenurial di Era Pemerintahan Joko Widodo}

Presiden Joko Widodo bersama dengan pasangannya Jusuf Kalla resmi menjadi pasangan Presiden dan Wakil Presiden ketujuh Indonesia setelah dilantik pada 20 Oktober 2014. Pergantian kepemimpinan nasional menjadi harapan bagi perubahan kebijakan pengelolaan Sumber Daya Alam (SDA) kea arah yang lebih baik. Pemerintah menjawab harapan itu dengan mengeluarkan kebijakan Reforma Agraria dan Perhutanan Sosial (RAPS) yang diformulasikan dalam sebuah dokumen legal yaitu Peraturan Presiden Nomor 2 Tahun 2015 tentang Rencana Pebangunan Jangka Menengah Nasional Tahun 2015-2019. Hal ini lebih rinci tertuang di dalam Lampiran Perpres tersebut dimana arah kebijakan yang diambil Pemerintah untuk peningkatan kesejahteraan rakyat adalah dengan reforma agraria yang dilakukan melalui beberapa

\footnotetext{
${ }^{44}$ Pasal 1 angka 7 Peraturan Menteri Lingkungan Hidup dan Kehutanan Nomor P.17/MENLHK/SETJEN/KUM.1/5/2018 tentang Tata Cara Pelepasan dan Perubahan Batas Kawasan Hutan untuk Sumber Tanah Objek Reforma Agraria (Berita Negara Republik Indonesia Tahun 2018 Nomor 738)

45 Tempo.co, "TORA Tawarkan Solusi Sengketa dan Konflik Dalam Kawasan Hutan," https://nasional.tempo.co/read/1062679/tora-tawarkan-solusi-sengketa-dan-konflik-dalam-kawasanhutan/full\&view=ok, diakses 29 September 2020

${ }^{46}$ Maria SW. Sumardjono, 2001, Transitional Justice atas "Hak Sumber Daya Alam”, dalam Komnas HAM: Keadilan Masa Transisi, Komisi Nasional Hak Asasi Manusia, Jakarta, hlm. 7
} 
cara. Antara lain dari beberapa cara tersebut adalah redistribusi tanah, legalisasi aset (sertifikasi tanah), sekaligus dilengkapi dengan bantuan pemberdayaan masyarakat kepada masyarakat berpenghasilan rendah yang membutuhkan, terutama petani, nelayan, usaha kecil menengah (UKM), dan masyarakat berpenghasilan rendah (MBR). ${ }^{47}$

Pemerintahan Joko Widodo-JK sendiri sejatinya tidak mendefinisikan ulang Reforma Agraria, melainkan masih merujuk definisi lama yang telah dihadirkan oleh para pakar. ${ }^{48}$ Merujuk pada pernyataan Kantor Staf Kepresidenan (KSP), Reforma Agraria adalah upaya menata ulang akses dan status hukum atas tanah dan sumber daya alam agar terwujudnya keadilan dalam penguasaan, pemilikan, penggunaan, dan pemanfaatan tanah, wilayah, serta sumber daya alam. ${ }^{49}$ Definisi ini kemudian terjabarkan dalam beberapa kebijakan Pemerintah baik melalui instrumen Perpres hingga Permen.

Secara umum, Perpres Nomor 2 Tahun 2015 mengehendaki adanya suatu legalisasi aset pada sektor kehutanan yang secara khusus diwujudkan dalam program pelepasan kawasan hutan negara sedikitnya seluas 4,1 juta ha sebagai bagian dari Tanah Objek Reforma Agraria (TORA). Hal ini tentu menjadi angin segar bagi sektor agraria dan SDA yang memiliki banyak permasalahan terutama terkait buruknya pengelolaan. Hal tersebut dikarenakan timpangnya penguasaan lahan, meskipun sejatinya sudah lama disadari sebagai masalah bersama, dan telah diupayakan jalan keluar.

Secara prinsipal, kebijakan-kebijakan yang dibuat Pemerintah terkait dengan SDA hendaknya merupakan suatu kesatuan peraturan-peraturan SDA yang saling sinergis dalam mencapai tujuan yang sama dan terikat oleh suatu pedoman etis, yaitu asas hukum pengelolaan SDA. Kebijakan yang dibuat harus mengikuti prinsip-prinsip pengelolaan SDA sebagaimana telah dimandatkan oleh TAP MPR No IX/MPR-RI/2001 tentang Pembaruan Agraria dan Pengelolaan Sumber Daya Alam (PAPSDA). Tentu juga memperhatikan prinsip dasar hubungan Negara dengan hutan yang antara lain adalah hubungan kekuasaan, yang bersifat public rechterlijk dan bukan merupakan hubungan kepemilikan. Lalu juga memperhatukan hubungan kekuasaan yang menunjukkan adanya kedaulatan Negara atas seluruh hutan. Serta meninjau kembali pengertian bahwa "dikuasai" bukan berarti "dimiliki", melainkan mengandung arti adanya kewajiban-kewajiban dan wewenang-wewenang dalam bidang hukum publik. ${ }^{50}$

Prinsip-prinsip yang termuat dalam TAP MPR tersebut diuraikan oleh beberapa prinsip antara lain: NKRI, HAM, Supremasi Hukum dengan mengakomodasi

\footnotetext{
${ }^{47}$ Lampiran I Peraturan Presiden Nomor 2 Tahun 2015 tentang Rencana Pembangunan Jangka Menengah Nasional Tahun 2015-2019, hlm. 146

${ }^{48}$ Muhammad Nazir Salim dan Westi Utami, 2019, Reforma Agraria, Menyelesaikan Mandat Konstitusi: Kebijakan Reforma Agraria dan Perdebatan Tanah Obyek Reforma Agraria, STPN Press, Yogyakarta, hlm. 64

${ }^{49}$ Ibid

${ }^{50}$ Bambang Pamulardi, 1999, Hukum Kehutanan dan Pembangunan Bidang Kehutanan, Raja Grafindo Persada, Jakarta, hlm. 271
} 
keragaman dan unifikasi hukum, pengutamaan kepentingan rakyat, demokrasi, transparansi, dan partisipasi, keadilan sosial, keberlanjutan, sensitivitas pada kearifan lokal, keterpaduan dan koordinasi antar-sektor, menghormati masyarakat hukum adat, keseimbangan hak dan kewajiban negara, pemerintah, masyarakat, dan individu serta desentralisasi. Prinsip-prinsip yang juga menjadi acuan pada arah kebijakan hukum yang terkait dengan persoalan pengelolaan SDA antara lain dapat ditemukan pada Putusan-Putusan MK. Putusan Mahkamah Konstitusi Nomor 34/PUU-IX/2011 memutuskan bahwa penguasaan hutan oleh Negara harus memperhatikan dan menghormati hak-hak atas tanah masyarakat. Putusan Mahkamah Konstitusi Nomor 45/PUU-IX/2011 memutuskan penghasilan Kawasan Hutan harus segera dituntasakan untuk menghasilkan kawasan hutan yang berkepastian hukum dan berkeadilan. Lalu Putusan Mahkamah Konstitusi Nomor 35/PUU-X/2012 mengatur bahwa hutan adat bukan merupakan hutan negara.

Selain itu, dalam pengelolaan hutan sebaiknya Pemerintah juga meperhatikan pilihan bentuk pengelolaan yang dinamis dan terfokus pada strategi kehutanan sosial. Ini berarti strategi kehutanan konvensional, yaitu timber management dan timber extraction, harus ditinggalkan, walaupun memerlukan masa transisi dengan jangka waktu yang sesingkat mungkin namun cukup realistis. ${ }^{51}$ Pengelolaan ini harus melihat masalah kesehatan ekosistem hutan misalnya, yang merupakan salah satu komponen yang diperlukan dalam menetapkan penilaian terhadap fungsi perlindungan. ${ }^{52}$

\subsubsection{Peraturan Bersama (Perber) 4 Menteri tentang Penyelesaian Penguasaan Tanah di Dalam Kawasan Hutan}

Meskipun Peraturan Bersama 4 Menteri yang dikeluarkan oleh Menteri Dalam Negeri, Menteri Pekerjaan Umum, Menteri Kehutanan, dan Badan Pertahanan Nasional ini dikeluarkan di periode kepemimpinan sebelumnya (14 Oktober 2014), namun pada praktiknya hal tersebut bergantung pada politik hukum yang berjalan di era kepemimpinan Joko Widodo. Hal ini tidak terlepas dari kenyataan bahwa setelah dituliskan dalam Nawacita, produk hukum yang berkaitan dengan resolusi konflik SDA tidak kunjung diformulasikan. Gagasan pada Perber 4 Menteri ini pun sebenarnya bukanlah gagasan yang benar-benar baru, melainkan merupakan artikulasi dari Nota Kesepahaman Bersama 12 Kementerian dan Lembaga (NKB 12 K/L) tentang percepatan pengukuhan kawasan hutan yang salah satu rencana aksinya adalah identifikasi dan pengakuan terhadap keberadaan hak-hak pihak ketiga yang ada di dalam kawasan hutan. ${ }^{53}$

\footnotetext{
${ }^{51}$ Hasanu Simon, 2008, Pengelolaan Hutan Bersama Rakyat (Cooperative Forest Management, Pustaka Pelajar, Yogyakarta, hlm. 106

${ }_{53}^{52}$ Ibid, hlm. 112

${ }^{53}$ Mumu Muhajir, "Satu Tahun Perber 4 Menteri tentang Penyelesaian Penguasaan Tanah di Dalam Kawasan Hutan: Kendala, Capaian, dan Arah ke Depan”, Policy Brief Vol. 02/2015, Epsitema InstituteJakarta, hlm. 2
} 
NKB ini dipandang sebagai momentum strategis bagi penataan atas sumbersumber agraria dan sumber daya hutan dalam upaya memulihkan fungsi sosial, ekonomi dan ekologi dari hutan. ${ }^{54}$ Perber ini lahir dari keresahan bahwa dalam pelaksanaannya, NKB belum memiliki ketentuan yang mengatur mengenai tata cara penyelesaian penguasaan atau hak-hak atas tanah yang berada dalam kawasan hutan, dimana kebijakan tersebut menyangkut kewenangan beberapa kementerian/lembaga negara, sehingga dinilai perlu menetapkan peraturan bersama. Perber 4 Menteri ini membawa angin segar dalam dinamika pengaturan resolusi penyelesaian konflik SDA. Disamping mengkonkretisasi NKB, Perber ini turut menjadi perwujudan semangat dari beberapa Putusan Mahkamah Konstitusi sebagaimana telah dipaparkan sebelumnya.

Perber 4 Menteri mengupayakan penyelesaian penguasaan tanah yang terdapat di dalam kawasan hutan melalui pelembagaan Inventarisasi Penguasaan, Pemilikan, Penggunaan, dan Pemanfaatan Tanah (IP4T), sebagai kegiatan pendataan yang diolah dengan sistem informasi geografis untuk menghasilkan peta dan informasi mengenai penguasaan tanah. Dalam menjalankan IP4T itu sendiri akan dilakukan oleh Tim yang dibentuk oleh Bupati/Walikota di masing-masing wilayah kewenangannya sesuai kawasan hutan terkait berada. Atau, oleh gubernur manakala penguasaan tanah yang diselesaikan berada dalam kawasan hutan yang sifatnya akan diselesaikan berada dalam kawasan hutan yang sifatnya lintas kabupaten/kota. ${ }^{55}$

Gambar1. Alur Penyelesaian Penguasaan Tanah di dalam Kawasan Hutan sebagaimana diatur dalam Perber 4 Menteri.

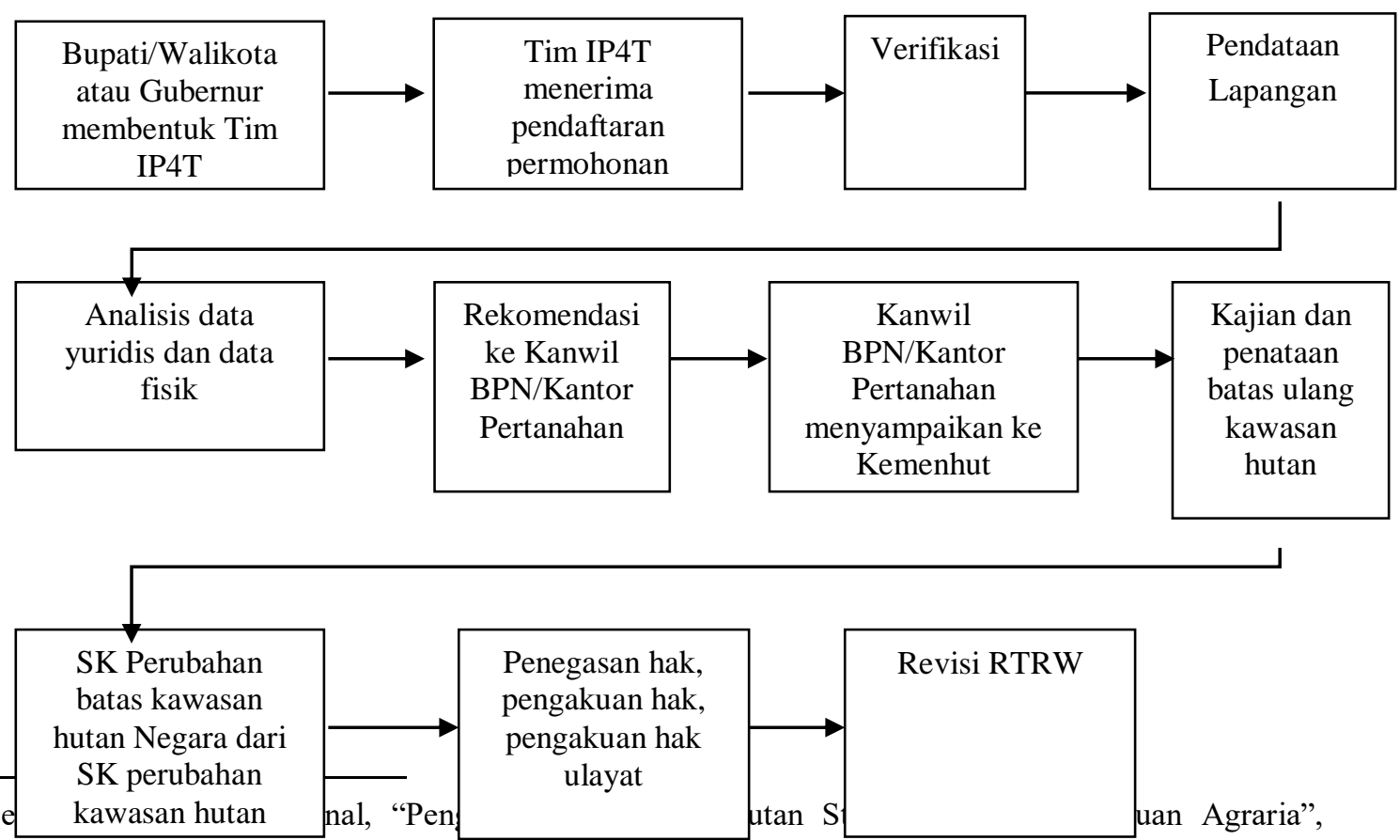

http://Www.dkn.or.id/2014/05/20/pengukuhan-kawasan-hutan-strategis-bagi-pembaruan-agraria/, diakses 29 September 2020

55 Pasal 2 dan 3 Peraturan Bersama Menteri Dalam Negeri Republik Indonesia, Menteri Kehutanan Republik Indonesia, Menteri Pekerjaan Umum Republik Indonesia, dan Badan Pertanahan Nasional Republik Indonesia Nomor 79 Tahun 2014 tentang Tata Cara Penyelesaian Penguasaan Tanah yang Berada di Dalam Kawasan Hutan 
Pengaturan resolusi konflik kawasan hutan pada Perber 4 Menteri tersebut menumbuhkan optimisme terhadap upaya penyelesaian konflik SDA yang berkeadilan. Hal ini terletak pada tidak adanya pembedaan perlakuan terhadap penguasaan tanah terkait dengan status kawasan hutan yang bersangkutan apakah terjadi sebelum atau setelah penunjukkan kawasan hutan. Dengan kata lain, kebijakan ini menyadari bahwa terhadap kawasan hutan yang telah berstatus definitif pun tidak sekedar ditunjuk, tetapi bahkan ditetapkan tidak otomatis berarti telah steril dari permasalah klaim tenurial. Oleh karenanya, terhadap sebuah kawasan hutan seharusnya tidak boleh langsung diasumsikan sama sekali telah clear dan clean dalam hal status penguasaannya.

\subsubsection{Perpres No. 88 Tahun 2017 tentang Penyelesaian Penguasaan Tanah Dalam Kawasan Hutan}

Permasalahan pelik pada implementasi Perber 4 Menteri dimana masing-masing kementerian merasa mempunyai legitimasi sesuai tupoksinya sendiri-sendiri sehingga pola koordinasi antar sektor yang relatif tidak dapat berjalan menjadi salah satu latar belakang dibentuknya Peraturan Presiden Nomor 88 Tahun 2017 tentang Penyelesaian Penguasaan Tanah Dalam Kawasan Hutan. Faktor lain yang menjadi alasan dibentuknya Perpres ini adalah faktor yuridis-formil dimana dalam UU Nomor 12 Tahun 2011 yang mengatur mengenai peraturan hukum yang diakui di Indonesia tidak dikenal adanya Peraturan Bersama. Secara umum Perpres ini dibentuk dalam rangka menyelesaikan dan memberikan perlindungan hukum atas hak-hak masyarakat dalam kawasan hutan yang menguasai tanah di kawasan hutan sehingga perlu dilakukan kebijakan penyelesaian penguasaan tanah dalam kawasan hutan. ${ }^{56}$

Rumusan Perpres yang diinsiasi oleh Kementerian LHK yang disampaikan pada pertemuan dengan Kementerian Dalam Negeri dan Kementerian ATR/BPN ini selain menjadikannya memiliki kekuatan hukum yang lebih kuat karena bentuknya sebagai Perpres, sesungguhnya juga diharapkan dapat mengakomodasi beberapa ketentuan yang terlewat dalam Peraturan Bersama seperti pentingnya penegasan status quo terhadap lahan yang sedang di-IP4T-kan, kompensasi atas lahan, penguatan koordinasi, penyesuaian dengan UU Pemerintahan Daerah, dan isu-isu lainnya. ${ }^{57}$ Salah satu substansi pokok pada Perpres ini adalah adanya proses penyelesaian dan pemberian perlindungan hukum terhadap hak-hak masyarakat dalam kawasan hutan agar penguasaan tanah di dalam kawasan hutan untuk pengukuhan kawasan hutan mempunyai jaminan kekuatan/kepastian hukum. Sebab sebagaimana diketahui bahwa Penguasaan Tanah dalam Kawasan Hutan negara (PTKH) merupakan masalah akut

\footnotetext{
${ }^{56}$ Konsiderans Peraturan Presiden Nomor 88 Tahun 2017 tentang Penyelesaian Penguasaan Tanah Dalam Kawasan Hutan ((Lembaran Negara Republik Indonesia Tahun 2017 Nomor 196)

${ }^{57}$ Ibid
} 
yang dari waktu ke waktu makin bertambah luas karena tidak segera terselesaikan. ${ }^{58}$ Hasil analisis berbagai peta tematik oleh Fakultas Kehutanan IPB pada tahun 2017 bahkan mengungkapkan, bahwa PTKH sendiri memiliki luas 17,4 juta hektar yang berada di dalam kawasan hutan konservasi, lindung, dan produksi, termasuk di dalam konsesi perusahaan hutan, izin tambang dan perkebunan. ${ }^{59}$

Sebagai bentuk pelembagaan dari niatan yang lahir dari semangat pembentuk undang-undang, maka Perpres tersebut mengamanatkan dibentuknya Tim Percepatan Penyelesaian Penguasaan Tanah dalam Kawasan Hutan yang selanjutnya disebut Tim Percepatan PPTKH, ${ }^{60}$ yang bertugas antara lain untuk menetapkan mekanisme Resettlement (sebagai salah satu solusi resolusi konflik), dan melakukan pengawasan dan pengendalian pelaksanaan penyelesaian penguasaan tanah dalam kawasan hutan; dan Tim Inventarisasi dan Verifikasi (Tim Inver) PTKH yang dibentuk oleh Gubernur di setiap Provinsi. Tim Inver PTKH bertugas melakukan inventarisasi PTKH berdasarkan pendaftaran permohonan inventarsiasi dan verifikasi yang diajukan oleh Pihak melaui Bupati/Walikota. Invetarisasi dalam konteks ini berupa kegiatan pendataan penguasaan, pemilikan, penggunaan, atau pemanfaatan tanah.

Selain melakukan pelembagaan, Perpes No. 88 Tahun 2017 juga memberikan arahan detail secara praktik dengan menyebutkan bahwa dalam rangka penyelesaian penguasaan tanah di dalam kawasan hutan, selanjutnya disusun sebuah Rencana Aksi yang akan ditetapkan melalui Peraturan Menko Perekonomian selaku Ketua Tim Percepatan Penyelesaian PTKH. Dalam rangka aksi jangka panjang 2018-2019, Tim Pelaksana Penyelesaian PTKH Kemenko Perekonomian menargetkan kegiatan identifikasi penguasaan tanah dalam kawasan hutan setiap kabupaten berjalan sepanjang Januari-Maret 2018 hingga 2019. ${ }^{61}$

\subsubsection{Peraturan Menteri P.17 Tahun 2018 tentang Tata Cara Pelepasan dan Perubahan Batas Kawasan Hutan untuk Sumber Tanah Objek Reforma Agraria (TORA)}

Peraturan Menteri Lingkungan Hidup dan Kehutanan ini merupakan peraturan yang lahir dalam rangka mengurangi ketimpangan penguasaan, pemilikan, penggunaan dan pemanfaatan tanah yang mengakibatkan ketimpangan struktur ekonomi masyarakat sebagaimana menjadi semangat Nawacita yang digagas oleh Pemerintahan Joko Widodo.

\footnotetext{
${ }^{58}$ Hariadi Kartodiharjo, "Titik Kritis Penyelesaian Penguasaan Tanah Dalam Kawasan Hutan, Opini Warta Online Agroindonesia", http//agroindonesia.co.id/2017/12/titik-kitis-penyelesaian-penguasaantanah-dalam-kawasan-hutan-2/ diakses 28 September 2020

${ }^{59}$ Ibid

${ }^{60}$ Pasal 14 Peraturan Presiden Nomor 88 Tahun 2017 tentang Penyelesaian Penguasaan Tanah Dalam Kawasan Hutan (Lembaran Negara Republik Indonesia Tahun 2017 Nomor 196)

${ }^{61}$ Tim Pelaksana Penyelesaian PTKH dalam Sosialisasi Perpres No. 88 Tahun 2017 tentang Penyelesaian PTKH
} 
Mekanisme penyelesaian konflik tenurial yang diatur melalui Peraturan Menteri Tahun 2018 ini adalah "revisi" kawasan hutan dalam bentuk pelepasan kawasan hutan dari Hutan Produksi yang dapat Dikonversi (HPK) tidak produktif, dan perubahan batas kawasan hutan dari kawasan hutan yang telah dikuasai, dimiliki, digunakan dan dimanfaatkan sebagai permukiman, lahan garapan, fasilitas umum dan/atau fasilitas sosial. ${ }^{62}$ Perbedaan dua mekanisme ini terletak pada peruntukannya, dimana untuk pelepasan HPK yang tidak produktif diperuntukkan untuk program pembangunan nasional dan daerah/pengembangan wilayah terpadu; pertanian tanaman pangan/pencetakan sawah baru; kebun rakyat; perikanan; peternakan; atau fasilitas pendukung budidaya pertanian. Sementara pada mekanisme perubahan batas kawasan hutan peruntukannya adalah permukiman, lahan garapan, fasilitas umum dan/atau fasilitas sosial sebelum bidang tanah tersebut ditunjuk sebagai kawasan hutan. Atau dengan kata lain adalah pada kawasan hutan yang telah terdapat tumpang tindih kepentingan, utamanya berupa peruntukan kegiatan yang sifatnya non-kehutanan.

\subsection{Implementasi Kebijakan Kebijakan Resolusi Konflik SDA}

Seperti fenomena hukum pada umumnya dimana das sollen tidak selaras dengan das sein, begitu pula terjadi dalam kebijakan resolusi konflik SDA di era Joko Widodo. Meskipun sudah menjadi salah satu perhatian Pemerintah (diwujudkan dalam Nawacita), akan tetapi pada faktanya praktik resolusi konflik yang berkeadilan masih jauh panggang dari api karena jumlah konflik laha yang tak kunjung menurun. Padahal idealnya, manajemen hutan yang semua elemennya sudah siap akan mewujudkan suatu pembangunan yang berkelanjutan dengan tujuan utama mengurangi jumlah penduduk miskin dan akhirnya menuju masyarakat makmur dan sejahtera. ${ }^{63}$ Hal tersebut senada dengan visi manajemen kehutanan di Indonesia yang tertuang dalam UU Nomor 41 Tahun 1999 Tentang Kehutanan. ${ }^{64}$

Secara formil, Peraturan Bersama 4 Menteri memiliki persoalan sebab eksistensinya yang tidak diakui oleh UU. Hal tersebut membuat upaya keberlakuannya menjadi tidak sekuat peraturan-peraturan yang diakui oleh UU. Selain rentan mengalami perubahan, hal ini juga menyebabkan keberlakuannya tidak kontinyu sebab terdapat potensi perubahan-perubahan nomenklatur Kementerian pada pergantian rezim. Secara normatif, Peraturan Bersama 4 Menteri pada dasarnya telah mengarah pada jalan yang positif, sayangnya pada impelementasinya tidak sebanding pada harapan yang disandarkan. Niat baik yang telah dibangun oleh masing-masing Kementerian yang terlibat dalam Peraturan tersebut masih terbentur oleh ego sektoral. Lembaga pendukung Perber 4 Menteri masih mengedepankan kepentingan masing-masing sektor

62 Pasal 3 Peraturan Menteri Lingkungan Hidup dan Kehutanan Nomor P.17/MENLHK/SETJEN/KUM.1/5/2018 tentang Tata Cara Pelepasan dan Perubahan Batas Kawasan Hutan untuk Sumber Tanah Objek Reforma Agraria (Berita Negara Republik Indonesia Tahun 2018 Nomor 738)

${ }^{63}$ Untung Iskandar Srihadiono dan Sambas Sabarnurdin, 2006, Globalisasi Sektor Kehutanan Indonesia, UNWAMA Press, Yogyakarta, hlm. 137

${ }^{64}$ Ibid 
yang menjadi kewenangannya alih-alih mengedepankan koordinasi dan kerjasama sebagaimana disuarakan pada narasi yang tertulis dalam peraturan bersama. Masingmasing Kementerian masih tetap bekerja sendiri-sendiri, meskipun dipantau secara ketat oleh KPK sebagai bagian Gerakan Nasional Penyelamatan SDA. ${ }^{65}$

Tantangan yang muncul dalam implementasi adalah adanya perubahan kebijakan mengenai kabinet dalam transisi kekuasaan dimana Presiden Joko Widodo memilih untuk melakukan reposisi kementerian dengan dileburkannya Lingkungan Hidup ke dalam Kementerian Lingkungan Hidup dan Kehutanan, dan kewenangan tata ruang dari Kementerian Pekerjaan Umum yang ditarik ke dalam Kementerian Agraria dan Tata Ruang/Badan Pertanahan Nasional (ATR/BPN). Secara organisasi peluang koordinasi dan kerjasama dalam penyelesaian tumpang tindih kawasan hutan seharusnya mejadi relatif lebih mudah karena beberapa lembaga diunifikasi, tetapi realitas yang terjadi tidak demikian. Ketiga kementerian yang terlibat dalam Perber (Kementerian LHK, Kementerian ATR/BPN dan Kementerian Dalam Negeri) masih tetap bekerja sendirisendiri. $^{66}$

Bukti tidak berjalannya koordinasi tersebut adalah tidak adanya sambutan baik dari Kementerian lain yang terkait perihal dikeluarkannya petunjuk pelaksanaan IP4T yang dikeluarkan oleh Kementerian ATR/BPN. Kementerian LHK merasa bahwa terbitnya petunjuk pelaksanaan yang tidak melibatkan mereka itu tidak sesuai dengan semangat Perber 4 Menteri. ${ }^{67}$ Dalam pandangan Kementerian LHK, seharusnya sebelum satu kementerian bertindak harus dimulai melalui berkoordinasi dengan kementerian yang lain terlebih dahulu, pada konteks ini, mestinya yang diterbitkan adalah petunjuk pelaksanaan bersama (Juklakber) oleh ketiga kementerian bersangkutan. ${ }^{68}$ Belum adanya Juklakber ini menjadi alasan bagi Kementerian LHK untuk tidak terlibat dalam pengumpulan data lapangan Tim IP4T, ${ }^{69}$ dan sebagai konsekuensinya membuat Perber 4 Menteri ibarat "antara ada dan tiada". Terlebih pada praktiknya, ternyata hanya Kementerian ATR/BPN yang paling berkomitmen untuk mencoba mengimplementasikan kebijakan dalam Perber 4 Menteri ini. Diantaranya melalui sosialisasi Perber 4 Menteri ke semua provinsi, menetapkan target kasar anggaran pelaksanaan IP4T per provinsi, mendorong pembentukan IP4T di daerah, dan salah satunya untuk membentuk suatu pedoman dalam melaksanakan penyelesaian penguasaan tanah yang berada di dalam kawasan hutan, maka diterbitkanlah petunjuk pelaksanaan penyelesaian penugasan tanah di dalam kawasan hutan pada Januari $2015 .^{70}$

Persoalan juga muncul dalam peraturan mengenai resolusi konflik SDA yaitu pada Perpres Nomor 88 Tahun 2017. Salah satunya adalah dalam hal pilihan resolusi

\footnotetext{
${ }^{65}$ Mumu Muhajir, Loc Cit

${ }^{66}$ Ibid., hlm. 2.

${ }^{67}$ Ibid

${ }^{68}$ Ibid

${ }^{69}$ Ibid

${ }^{70}$ Ibid
} 
konflik. Bentuk penyelesaian PTKH melalui resettlement sesungguhnya bisa dikatakan merupakan pilihan solusi yang tidak realistis untuk dilaksanakan dalam konteks masalah tenurial kawasan hutan. Dengan menyadari bahwa tanah adalah ruang hidup (lebensraum) karena di dalamnya terdapat relasi emosional, sosial, dan budaya dengan penghuninya, maka penyelesaian PTKH dengan bentuk resettlement merupakan penyederhanaan persolan secara sewenang-wenang. Sulit dibayangkan bagaimana masyarakat hukum adat harus dipindahkan keluar kawasan yang notabene merupakan wilayah ulayat dan teritori leluhurnya (ancestral territory). ${ }^{71}$

Terbaru, norma dalam Permen LHK P.17 ini juga tidak lebih baik dalam mengatur mekanisme perubahan batas kawasan hutan. Sebab ketentuan-ketentuan yang ada tidak banyak memberikan terobosan yang signifikan sebagai sebuah instrument kebijakan resolusi konflik tenurial kawasan hutan. Norma di dalam peraturan ini kembali menegaskan bahwa kawasan hutan yang dapat dikeluarkan dari kawasan hutan (enclave), adalah kawasan yang harus berada dalam Peta Indikatif Alokasi Kawasan Hutan untuk Penyediaan TORA. Peraturan ini juga membatasi melalui kriteria kawasan hutan selayaknya yang diatur dalam Perpres Nomor 88 Tahun 2017.

Keluarnya peraturan ini juga tidak memberi kabar baik bagi tawaran resolusi konflik kawasan hutan melalui TORA. Sebab apabila merujuk pada kebijakan ini, perubahan kawasan hutan yang telah ditunjuk melalui perubahan batas (enclave) untuk tujuan mengakomodasi fenomena penguasaan tanah dalam kawasan hutan yang bentuknya adalah lahan garapan, permukiman dan fasilitas umum/sosial tidak dimungkinkan terjadi di kawasan hutan lindung maupun hutan produksi yang luas kawasan hutannya kurang dari 30 persen. Sehingga untuk wilayah-wilayah yang berada di Jawa, Lampung, dan Bali, yang kondisinya memiliki luas kawasan hutan kurang dari 30 persen hanya dapat dilakukan resolusi konflik dengan skema PS, dan itupun untuk konteks kawasan hutan sebagai lahan garapan.

Sementara untuk permukiman dan fasilitas umum/sosial hanya dapat dikeluarkan dari kawasan hutan dengan enclave manakala dapat membuktikan bahwa bentuk penguasaan tersebut telah ada sebelum penunjukan kawasan hutan. Tentu persyaratan ini sulit dipenuhi, khususnya di wilayah Jawa yang mana penunjukan kawasan hutan dianggap telah ada sejak jaman colonial "Hindia-Belanda".

\section{Simpulan}

Sebagaimana telah dibahas di tulisan ini, program reforma agraria merupakan salah satu poin penting yang tertuang dalam cita-cita pemerintahan Joko Widodo. Berdasarkan hal tersebut, maka seharusnya program reforma agraria sedikitnya

\footnotetext{
${ }^{71}$ Agung Wibowo, dkk, "Dari Reformasi Kembali ke Orde Baru: Tinjauan Kritis Perpres No. 88 Tahun 2017”, Opini Hukum AMAN, Epistema Institute, dan Perkumpulan Huma Oktober 2017, hlm. 4, http://epistema.or.id/wp-content/uploads/dlm_uploads/2017/10/Opini_Hukum_2017.pdf, diakses 30 September 2020
} 
menunjukkan dua poin penting, Pertama, menunjukkan bahwa isu agraria termasuk di dalamnya adalah pengelolaannya merupakan isu sentral dan strategis bagi pemerintah dan masyarakat. Kedua, bahwa pemerintah seharusnya menunjukkan komitmen serius dengan kebijakan-kebijakan yang strategis dan implementatif. Kebijakan strategis yang dimaksud adalah kebijakan yang benar-benar melibatkan seluruh stakeholder terkait untuk terlibat dalam satu regulasi yang mencakup seluruh tugas, wewenang, dan kewajiban para stakeholder sehingga tidak menimbulkan tumpang tindih kewenangan. Kebijakan implementatif yang dimaksud adalah kebijakan yang memungkinkan untuk dilaksanakan sesuai dengan prinsip-prinsip pengelolaan sumber daya alam, peraturan perundang-undangan yang telah ada sebelumnya, maupun sesuai dengan kondisi di lapangan sebagai obyek dari kebijakan yang dibuat.

Dalam perkembangannya pembentukan peraturan-peraturan yang mengatur mengenai resolusi konflik tenurial juga tidak menunjukkan perkembangan signifikan ke arah yang lebih baik. Setelah kurun 2011-2014, sesungguhnya kebijakan-kebijakan yang muncul sangat positif melalui berbagai Nota Kesepahaman Bersama, dan Peraturan Bersama 4 Menteri. Namun, selepas itu kebijakan yang muncul justru cenderung stagnan. Sebab, alih-alih menumbuhkan optimisme yang sempat muncul pada kebijakan-kebijakan sebelumnya, kebijakan terbaru justru memunculkan pesimisme dalam pengaturan resolusi konflik tenurial.

Peraturan-peraturan yang eksis di era Joko Widodo dalam rangka mengatasi konflik tenurial yang terjadi, sejauh ini memiliki beberapa kekurangan. Perber 4 Menteri merupakan produk hukum yang keberadaannya tidak diatur oleh UU sehingga memiliki legitimasi yang lemah. Implementasi dari Perber ini juga memiliki kendala karena masih terbentur oleh ego sektoral lembaga terkait. Alih-alih mengedepankan koordinasi dan kerjasama, lembaga yang terkait dengan Perber 4 Menteri masih mengedepankan kepentingan masing-masing sektor yang menjadi kewenangannya.

Pola penyelesaian konflik tenurial melalui pelembagaan yang ditunjukkan oleh Perpres No. 88 Tahun 2017 juga memiliki permasalahan. Perpres ini memilih mekanisme resettlement sebagai upaya resolusi konflik. Bentuk penyelesaian tersebut dapat dikatakan sebagai pilihan solusi yang tidak realistis untuk dilaksanakan dalam konteks masalah tenurial kawasan hutan. Hal ini mengingat tanah adalah ruang hidup (lebensraum), karena di dalamnya terdapat relasi emosional, sosial, dan budaya dengan penghuninya, maka penyelesaian PTKH dengan bentuk resettlement merupakan penyederhanaan persolan secara sewenang-wenang. Sulit dibayangkan bagaimana masyarakat hukum adat harus dipindahkan keluar kawasan yang notabene merupakan wilayah ulayat dan teritori leluhurnya (ancestral territory).

Sementara Permen LHK P.17 ini juga tidak lebih baik dalam mengatur mekanisme perubahan batas kawasan hutan. Sebab, norma di dalam peraturan ini menyebutkan bahwa kawasan hutan yang dapat dikeluarkan dari kawasan hutan (enclave) adalah kawasan yang harus berada dalam Peta Indikatif Alokasi Kawasan 
Hutan untuk Penyediaan TORA. Peraturan ini juga membatasi kriteria kawasan hutan sebagaimana diatur dalam Perpres Nomor 88 Tahun 2017. Selain itu, tawaran resolusi konflik kawasan hutan melalui TORA juga tidak akomodatif karena tidak dimungkinkan terjadi di kawasan hutan lindung maupun hutan produksi yang luas kawasan hutannya kurang dari 30 persen. Sehingga untuk wilayah-wilayah yang memiliki luas kawasan hutan kurang dari 30 persen hanya dapat dilakukan resolusi konflik dengan skema PS, dan itupun untuk konteks kawasan hutan sebagai lahan garapan.

Dengan dibentuknya peraturan-peraturan yang justru tidak menyelesaikan persoalan konflik tenurial ini menunjukkan adanya diskontinyuitas dalam penyelesaian koflik tenurial. Keseriusan Pemerintah seharusnya diwujudkan dengan mengevaluasi segala peraturan terkait dengan merevisi peraturan dengan melengkapi kekurangan norma yang ada atau membentuk regulasi yang lebih tinggi dari pada sekedar Peraturan Menteri (Permen) maupun Peraturan Presiden (Perpres) yaitu Peraturan Pemerintah (PP). Meskipun peraturan selevel Peraturan Menteri tetapl penting sebagai acuan teknis, tetapi hal ini perlu dilakukan agar tercipta harmonisasi peraturan di bawahnya, sehingga kemungkinan adanya ego sektoral dari setiap kementerian atau lembaga dapat dibatasi melalui PP yang dibentuk. Namun demikian, untuk mewujudkan hal ini dibutuhkan keseriusan dari seluruh stakeholder terkait yang terlibat dalam pembentukan undangundang agar tidak tumpang tindih dan untuk memperoleh kesamaan pandangan terhadap upaya penyelesaian konflik tenurial. Melihat pengalaman bahwa Pemerintah pernah membentuk Peraturan Bersama 4 Menteri menunjukkan bahwa pengelolaan sumber daya termasuk di dalamnya resolusi konflik kawasan hutan merupakan isu lintas sektor sehingga dibutuhkan payung hukum yang memadai. Disamping isu pengelolaan sumber daya alam merupakan sesuatu yang vital, mengingat telah diatur di dalam konstitusi.

\section{Daftar Pustaka}

\section{Buku}

Awang, San Afri, 2007, Politik Kehutanan Masyarakat, Kreasi Wacana, Yogyakarta.

Badan Pertanahan Nasional, 2007, Reforma Agraria: Mandat Politik, Konstitusi, dan Hukum Dalam Rangka Mewujudkan "Tanah untuk Keadilan dan Kesejahteraan Rakyat”, BPN, Jakarta.

Colfer, Carol J. Pierce dan Ida Aju Pradnja Resosudarmo (Ed.), 2002, Which Way Forward? People, Forests, and Policymaking in Indonesia, RFF Press Book, Washington.

Cooke, Fadzilah Madjid (Ed.), 2006, State, Communitiesand Forests in Contemporary Borneo, ANU Press, Canberra.

Fajar, Mukti dan Yulianto Achmad, 2010, Dualisme Penelitian Hukum Normatif dan Empiris, Pustaka Pelajar, Yogyakarta. 
Larson, Anne M., 2013, Hak Tenurial dan Akses ke Hutan, Center for Intenational Forestry Research, Bogor.

Pamulardi, Bambang, 1999, Hukum Kehutanan dan Pembangunan Bidang Kehutanan, Raja Grafindo Persada, Jakarta.

Pasya, Gamal , 2017, Penanganan Konflik Lingkungan: Kasus Pengelolaan Kawasan Hutan Lindung Bukit Rigis Lampung, Gramedia Pustaka Utama, Jakarta.

Salim, Muhammad Nazir dan Westi Utami, 2019, Reforma Agraria, Menyelesaikan Mandat Konstitusi: Kebijakan Reforma Agraria dan Perdebatan Tanah Obyek Reforma Agraria, STPN Press, Yogyakarta

Sardjono, Mustofa Agung, 2004, Mosaik Sosiologi Kehutanan : Masyarakat Lokal, Politik dan Kelestarian Sumberdaya, Debut Wahana Sinergi, Yogyakarta.

Simon, Hasanu, 2008, Pengelolaan Hutan Bersama Rakyat (Cooperative Forest Management), Pustaka Pelajar, Yogyakarta.

Soekanto, Soerjono dan Sri Mamudji, 2006, Penelitian Hukum Normatif, Raja Grafindo Persada, Jakarta.

Srihadiono, Untung Iskandar dan Sambas Sabarnurdin, 2006, Globalisasi Sektor Kehutanan Indonesia, UNWAMA Press, Yogyakarta

Sumardjono, Maria SW., 2001. Transitional Justice atas Hak Sumber Daya Alam, dalam Komnas HAM: Keadilan Masa Transisi, Komnas HAM, Jakarta.

\section{Jurnal}

Anwar, Khairul, "The Pattern of Interaction Politicalactors on Situations of Tenurial conflict in Watershedcase of Palm Oil in Kampung Dosan", Journal of Science and Technology Policy Management Vol. 10 No. 5, 2019

Arfani , Riza Noer, “Governance sebagai Pengelolaan Konflik”, Jurnal Ilmu Sosial Ilmu Politik FISIPOL UGM, Vol. 8 No. 3, Maret 2005.

Erlina, "Kebijakan Reformasi Agraria pada Masa Pemerintahan Joko Widodo Ditinjau dari Kajian HAM dan Gender”, Riau Law Journa, Vol. 1 No.2, November 2017

Hakim, Luchman dkk, "Peran dan Dampak Konflik Tenurial Kehutanan bagi Pengelolaan Keanekaragaman Hayati di Kawasan Cagar Biosfer di Jawa Timur", Jurnal Hutan Tropis, Volume 6, Nomor 1, Maret 2018

Maryudi, Ahmad dkk. "The emerging power of peasant farmers in the tenurial conflicts over the uses of state forestland in Central Java, Indonesia", Journal Forest Policy and Economics, Volume 67, June 2016.

Suhardono, Wisnu, "Konflik dan Resolusi”, Jurnal Sosial dan Budaya Syar'I Universitas Islam Islam Negeri Syarif Hidayatullah, Vol. II No. 1 Juni 2015. 
Hakim, Ismatul \& Sylviani, "Analisis Tenurial dalam Pengembangan Kesatuan Pengelolaan Hutan (KPH): Studi Kasus KPH Gedong Wani, Provinsi Lampung", JURNAL Penelitian Sosial dan Ekonomi Kehutanan, Vol. 11 No. 4 Desember 2014.

Muhajir, Mumu, "Satu Tahun Perber 4 Menteri tentang Penyelesaian Penguasaan Tanah di Dalam Kawasan Hutan: kendala, capaian, dan arah ke depan", Policy Brief Vol. 02/2015, Epsitema Institute-Jakarta.

\section{Makalah}

Anonim, 2013. "Menuju Kawasan Hutan yang Berkepastian Hukum dan Berkeadilan," Prosiding Semiloka (integrated white paper), Komisi Pemberantasan Korupsi (KPK), Jakarta 13 Desember 2012, hlm. 4

Saputra, Joni dan Endang Dewata, "Tenurial conflict between parties in the technical implementation unit of the Banjar Regency Forest Management Unit in the Province of South Kalimantan", The 1st International Conference on Environmental Sciences (ICES 2018)

Tim Pelaksana Penyelesaian PTKH, "Sosialisasi Perpres No. 88 Tahun 2017 tentang Penyelesaian PTKH”, materi presentasi 2017, tidak dipublikasikan.

\section{Disertasi}

Marzuki, Agus. 2016. "Penyelesaian Konflik Tenurial Kawasan Hutan Register 45 Mesuji Lampung dalam Perspektif Keadilan”. Disertasi. Fakultas Hukum, Universitas Gadjah Mada, Yogyakarta.

\section{Peraturan Perundang-Undangan}

Peraturan Presiden Nomor 2 Tahun 2015 tentang Rencana Pembangunan Jangka Menengah Nasional Tahun 2015-2019

Peraturan Presiden Nomor 88 Tahun 2017 tentang Penyelesaian Penguasaan Tanah Dalam Kawasan Hutan

Peraturan Menteri P.17 Tahun 2018 tentang Tata Cara Pelepasan dan Perubahan Batas Kawasan Hutan untuk Sumber Tanah Objek Reforma Agraria (TORA)

Peraturan Bersama Menteri Dalam Negeri Republik Indonesia, Menteri Kehutanan Republik Indonesia, Menteri Pekerjaan Umum Republik Indonesia, dan Badan Pertanahan Nasional Republik Indonesia Nomor 79 Tahun 2014 tentang Tata Cara Penyelesaian Penguasaan Tanah yang Berada di Dalam Kawasan Hutan 


\section{Website}

Apriando, Tommy, "Kajian UGM: 2,8 Juta Hektar Kebun Sawit di Kawasan Hutan, 65\% Milik Pengusaha, Solusinya?", https://www.mongabay.co.id/2018/11/04/kajian-ugm-28-juta-hektar-kebunsawit-di-kawasan-hutan-65-milik-pengusaha-solusinya/, diakses tanggal 2 April 2020.

CNN Indonesia, "Konflik Lahan Era Joko Widodo 2 Kali Lipat dari 2 Periode SBY", https://www.cnnindonesia.com/nasional/20200106132321-20-462771/konfliklahan-era-Joko Widodo-2-kali-lipat-dari-2-periode-sby, diakses pada 29 September 2020.

Tempo.co, "TORA Tawarkan Solusi Sengketa dan Konflik Dalam Kawasan Hutan," https://nasional.tempo.co/read/1062679/tora-tawarkan-solusi-sengketa-dankonflik-dalam-kawasan-hutan/full\&view=ok, diakses pada tanggal 29 September 2020. 